\title{
Article \\ Performance of Hydroponically Cultivated Geranium and Common Verbena under Salinity and High Electrical Conductivity Levels
}

\author{
Antonios Chrysargyris ${ }^{1}$, Spyridon A. Petropoulos ${ }^{2}$ (D) Dejan Prvulovic ${ }^{3}$ and Nikolaos Tzortzakis ${ }^{1, *(D)}$ \\ 1 Department of Agricultural Sciences, Biotechnology and Food Science, Cyprus University of Technology, \\ Limassol 3603, Cyprus; a.chrysargyris@cut.ac.cy \\ 2 Laboratory of Vegetable Production, University of Thessaly, Fytokou Street, N. Ionia, 38446 Volos, Greece; \\ spetropoulos@uth.gr \\ 3 Department of Field and Vegetable Crops, University of Novi Sad, 21000 Novi Sad, Serbia; \\ dejan.prvulovic@polj.uns.ac.rs \\ * Correspondence: nikolaos.tzortzakis@cut.ac.cy
}

\section{check for} updates

Citation: Chrysargyris, A.; Petropoulos, S.A.; Prvulovic, D.; Tzortzakis, N. Performance of Hydroponically Cultivated Geranium and Common Verbena under Salinity and High Electrical Conductivity Levels. Agronomy 2021, 11, 1237. https://doi.org/10.3390/ agronomy11061237

Academic Editor: Byoung Ryong Jeong

Received: 24 May 2021

Accepted: 17 June 2021

Published: 18 June 2021

Publisher's Note: MDPI stays neutral with regard to jurisdictional claims in published maps and institutional affiliations.

Copyright: (c) 2021 by the authors Licensee MDPI, Basel, Switzerland. This article is an open access article distributed under the terms and conditions of the Creative Commons Attribution (CC BY) license (https:/ / creativecommons.org/licenses/by/ $4.0 /$ )

\begin{abstract}
Abiotic factors in nutrient solutions (NSs), such as salinity and high electrical conductivity (EC), may adversely alter plant growth and crop performance. However, there are medicinal/aromatic plants which can not only withstand these adverse conditions, but which can also increase their productivity or even enhance their quality in such conditions. As fresh water sources suitable for irrigation are becoming more and more limited, the use of low-quality water sources and hydroponic growing systems have been suggested as the main alternatives. Towards that direction, this study aims to evaluate the effect of high EC levels in NSs on geranium (Pelargonium graveolens L'Hér.) and common verbena (Verbena officinallis L.) plants cultivated in a soilless (perlite) hydroponics system. Plants were irrigated with a full nutrient solution of EC $2.1 \mathrm{dS} \mathrm{m} \mathrm{m}^{-1}$ and $\mathrm{pH}$ 5.8 until they reached a uniform size. Then, three treatments were applied, namely: (a) a control treatment with an EC of $2.1 \mathrm{dS} \mathrm{m}^{-1}$ in the NS, (b) a high-salinity NS created by adding $75 \mathrm{mM}$ of $\mathrm{NaCl}$ (EC under $8.5 \mathrm{dS} \mathrm{m}^{-1}$ ) and (c) a concentrated NS with an EC of $8.5 \mathrm{dS} \mathrm{m}^{-1}$. In pelargonium, high salinity decreased the total phenolic and total flavonoid contents; antioxidant capacity; $\mathrm{N}, \mathrm{K}, \mathrm{Mg}$ and $\mathrm{P}$ content; as well as chlorophyll fluorescence, compared to the control treatment. On the other hand, increased salinity levels increased the $\mathrm{Na}$ and $\mathrm{Ca}$ content and stomatal resistance. In common verbena, salinity decreased total phenolic content and chlorophyll fluorescence but increased total flavonoid content; antioxidants; leaf $\mathrm{K}, \mathrm{P}, \mathrm{Na}, \mathrm{Cu}$ and $\mathrm{Zn}$ content; and stomatal resistance, compared to the control. In both species, high EC did not affect polyphenols, flavonoids or antioxidants, whereas it increased stomatal resistance and nutrient accumulation in the leaves, and decreased chlorophyll fluorescence compared to the control treatment. Damage indices, indicated by lipid peroxidation, hydrogen peroxide production and the elevation of enzymes' antioxidant activities, were evidenced in both saline- and high-EC-treated plants. In conclusion, despite having the same EC levels in the nutrient solution, it seems that ionic stress caused by high mineral concentrations in the nutrient solution had less severe effects on the tested plants than the relevant osmotic stress caused by high salinity due to the addition of $\mathrm{NaCl}$ in the nutrient solution.
\end{abstract}

Keywords: Pelargonium graveolens; Verbena officinallis; hydroponics; secondary metabolites; poor quality water; saline conditions

\section{Introduction}

Water quality and availability are critical, as water is the most scarce and/or poorly controlled natural resource, and there is an urgently growing need for adequate water conservation practices, especially in the arid and semiarid regions of the Mediterranean basin [1]. Salinity is a growing problem in agricultural soils around the world, with $6 \%$ 
of the world's land and $20 \%$ of irrigated land affected by salinization, especially in arid regions [2]. The severe effects of salinity occur when salts build up in the crop root zone at a concentration that may result in low yield or affect seed germination and water/nutrient uptake from plants and subject crops to osmotic stress [3-8]. Therefore, salinity is regarded as one of the most significant abiotic stressors, restricting crop production in arid and semi-arid areas where the salt content in the soil is normally high and precipitation is inadequate to allow leaching [3,5,6]. Electrical conductivity (EC) or total dissolved solids (TDS), as well as total soluble cations (TSC) and total soluble anions (TSA), are commonly used to describe salinity in soils and irrigation water. Various strategies against salinity have been suggested, including salts leaching below the plants' root zone, the reduction of soil evaporation and increased drainage, and the implementation of efficient irrigation management, to name a few [9].

The most apparent effect of salinity is a reduction in the plant growth rate due to osmotic and ionic impacts [10]. As a consequence of a long-lasting stress, additional energy is required by plant cells and less carbon is available for growth $[10,11]$. Moreover, saltinduced osmotic stress affects the turgor and expansion of the plant cell [12]. According to Munns [13], a stronger inhibition of salt-stressed plants is possible at low salinity levels compared to higher ones, and this could be explained by the fact that salinity in the short-term may affect plant growth due to osmotic effects that limit cell expansion. In the long-term, secondary effects may arise, including excessive salt uptake, which may expose plants to ionic stress [14].

Managing EC levels in the nutrient solution is one of the fundamental skills required for running an efficient hydroponic setup [15]. Inadequate or excessive concentrations of minerals or an imbalanced ion composition in the nutrient solution may inhibit plant development, resulting in toxicity or nutrient-induced deficiencies [16]. High ionic concentrations can disrupt membrane integrity and function, as well as internal solute balance and nutrient absorption, resulting in nutritional deficiency symptoms similar to those observed when nutrient concentrations are below the required levels [16]. However, managing the EC in moderately high levels - either by using low-quality water that contains residual ions, such as $\mathrm{Cl}^{-}, \mathrm{Na}^{+}$and $\mathrm{SO}_{4}{ }^{-}$, or by adding major nutrients through stock solutions-is a cultivation management technique that provides great potential to achieve high dietary and organoleptic quality in fresh tomatoes [17,18], spearmint [5,19] and sage [20].

Medicinal and aromatic plants (MAPs) have gained recent popularity in industry, academia and health sciences, mostly due to their strong antioxidant and antimicrobial properties, which may outperform many widely used natural and synthetic antioxidants and antimicrobial agents. The properties of MAPs are related to their rich contents of vitamins, catechins, phytoestrogens, carotenoids, chlorophylls, minerals, etc., which highlight their use as food preservatives [20-22]. Regarding the effect of salinity on plant growth and essential oil yield production in MAPs, contrasting results have been reported in the literature, mostly due to differences in the degree of stress tested or to possible plant recovery after stress [11,23]. Moreover, considering the increasing problem of soil and irrigation water salinization, there is a growing interest in salt-tolerant species, especially for landscaping purposes $[8,24]$. Several MAP species have been proposed for landscaping, including Pelargonium graveolens and Verbena officinallis. The Pelargonium genus belongs to the Geraniaceae family and embraces several hundreds of aromatic species, distributed worldwide in subtropical and temperate regions [25]. The pharmacological activity of Pelargonium spp. is mainly attributed to phenolic constituents such as flavonoids and hydroxycinnamic acid-derivatives [26], whereas Pelargonium graveolens, commonly known as rose-scented geranium, has been reported in several studies as a good candidate for phytoremediation purposes [27]. On the other hand, Verbena officinalis (commonly known as "Vervian," "Herb of grace" or "Pigeon's grass") is a perennial herb and a member of the Verbenaceae family, which mostly grows in Europe and Asia and is highly appreciated for its numerous medicinal properties, as reviewed by Khan et al. [28]. 
Considering the increasing problems that soil and irrigation water salinization poses to global crop production, there is an urgent need to propose sustainable and cost-effective practices that may alleviate its negative effects on plant growth, crop performance and final product quality. In this context, the aim of this study was to determine the effect of nutrient solutions (NSs) with high EC levels $\left(8.5 \mathrm{dS} \mathrm{m}^{-1}\right)[29,30]$ due to high minerals or high $\mathrm{NaCl}$ concentrations on the growth and development of Pelargonium graveolens and Verbena officinallis plants grown in a soilless (perlite substrate) cultivation system.

\section{Materials and Methods}

\subsection{Experimental Setup and Plant Material}

Pelargonium graveolens and Verbena officinallis plants were purchased from a local nursery and transplanted at the stage of 3 true leaves in pots (one plant per pot; $0.5 \mathrm{~L}$ capacity) filled with expanded perlite. The transplanted plants in pots were placed on plastic trays $(30 \mathrm{~cm} \times 20 \mathrm{~cm})$ to achieve proper drainage. The properties of perlite have been described previously in the literature [31]. Plants were grown in an open (free drainage) pot substrate culture system, and the drainage nutrient solution was available to plants through capillary suction.

Plants were initially grown with the application of a full-strength nutrient solution (with electrical conductivity (EC) and $\mathrm{pH}$ values of $2.1 \mathrm{mS} \mathrm{cm}^{-1}$ and 5.7 , respectively) for 21 days in a fully climate-controlled greenhouse. The nutrient solution composition was: $\mathrm{NO}_{3}{ }^{-}-\mathrm{N}=15.00 \mathrm{mmol} \mathrm{L}^{-1}, \mathrm{~K}=9.50 \mathrm{mmol} \mathrm{L}^{-1}, \mathrm{PO}_{4}{ }^{-3}-\mathrm{P}=1.80 \mathrm{mmol} \mathrm{L}^{-1}, \mathrm{Ca}=4.20 \mathrm{mmol}$ $\mathrm{L}^{-1}, \mathrm{Mg}=1.63 \mathrm{mmol} \mathrm{L}{ }^{-1}, \mathrm{SO}_{4}^{-2}-\mathrm{S}=1.55 \mathrm{mmol} \mathrm{L}{ }^{-1}$ and $\mathrm{Na}=1.85 \mathrm{mmol} \mathrm{L}^{-1}$; and $\mathrm{B}=30.00 \mu \mathrm{mol} \mathrm{L}{ }^{-1}, \mathrm{Fe}=35.05 \mu \mathrm{mol} \mathrm{L}{ }^{-1}, \mathrm{Mn}=6.10 \mu \mathrm{mol} \mathrm{L}{ }^{-1}, \mathrm{Cu}=4.00 \mu \mathrm{mol} \mathrm{L}{ }^{-1}$, $\mathrm{Zn}=4.10 \mu \mathrm{mol} \mathrm{L}^{-1}$ and $\mathrm{Mo}=0.52 \mu \mathrm{mol} \mathrm{L}{ }^{-1}$, based on previous studies [32]. After that time period, three different treatments were applied, namely (a) plants grown in the same solution as previously described, (b) plants grown under $8.5 \mathrm{dS} \mathrm{m}^{-1}$ of salinity (in terms of $75 \mathrm{mM} \mathrm{NaCl}$ ), and (c) plants grown under high electrical conductivity (in terms of concentrated NS with an EC of $8.5 \mathrm{dS} \mathrm{m}^{-1}$ ) (Figure 1). In both treatments, plants were grown under the specified conditions for 30 days and were fertigated daily. Each treatment consisted of twelve pots (36 pots in total), arranged according to a completely randomized design (CRD).

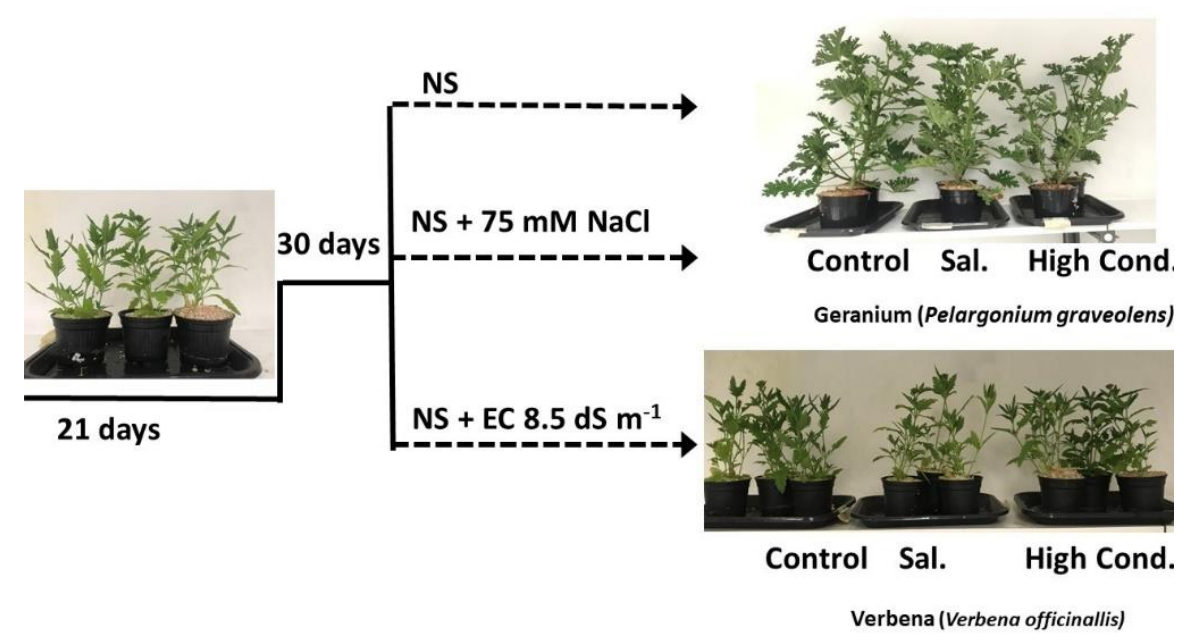

Figure 1. Experimental setup of the effects of salinity (Sal.; $75 \mathrm{mM} \mathrm{NaCl}$ ) and high electrical conductivity (High Cond.; $8.5 \mathrm{dS} \mathrm{m}^{-1}$ ) on geranium and common verbena plants grown hydroponically in perlite substrate. NS indicates nutrient solution.

\subsection{Plant Growth and Physiological Measurements}

Plant growth and physiological parameters were measured in six replicates per treatment. In particular, plant height and leaf number were recorded at the completion of the study, before harvesting. After harvesting, the fresh and dry weights of aerial plant parts 
were measured. Individual samples were collected and placed in a forced-air oven at $85{ }^{\circ} \mathrm{C}$ until a constant weight was reached in order to record their dry weight.

Leaf stomatal resistance was measured with a $\Delta \mathrm{T}$-Porometer AP4 (Delta-T DevicesCambridge, Burwell, Cambridge, UK) [5]. Leaf chlorophyll fluorescence (chlorophyll fluorometer, Opti-Sciences OS-30p, UK) and SPAD levels were measured in two fully developed, light-exposed leaves per plant. The Fv/Fm ratio was measured after the incubation of leaves in the dark for $20 \mathrm{~min}$ [5]. Leaf chlorophyll content was assayed in six replicates/treatment. In brief, chlorophyll was extracted with dimethyl sulfoxide (DMSO) and chlorophyll a (Chl a), chlorophyll b $(\mathrm{Chl} \mathrm{b})$ and total chlorophyll (total Chl) content were calculated according to the methodology previously described by Chrysargyris et al. [5]. The results were expressed in $\mathrm{mg} \mathrm{g}^{-1}$ fresh weight.

\subsection{Antioxidant Activity, Total Phenolic and Total Flavonoid Content}

The antioxidant activity of the methanolic plant extracts was determined using the assays with 2,2-diphenyl-1-picrylhydrazyl (DPPH) and ferric reducing antioxidant power (FRAP), as previously described by Chrysargyris et al. [33], as well as the 2,2'-azinobis(3-ethylbenzothiazoline-6-sulphonic acid) (ABTS) assay according to the methodology described by Woidjylo et al. [34]. The Folin-Ciocalteu method was used for the determination of the total phenol content, as previously described [35], and results were expressed as gallic acid equivalents (mg GAE per $\mathrm{g}$ of fresh weight). The total flavonoid content was determined according to the aluminum chloride colorimetric method [36] and results were expressed as rutin equivalents (mg rutin per $\mathrm{g}$ of fresh weight).

\subsection{Mineral Content}

Dried tissue $(0.5 \mathrm{~g})$ from the aerial plant parts from each treatment ( 4 biological replications; each replication was a pool of 2 individual plants) was ashed $\left(450{ }^{\circ} \mathrm{C}\right)$ and acid-digested $(2 \mathrm{~N} \mathrm{HCl})$ for nutrient extraction. Sodium $(\mathrm{Na})$ and potassium $(\mathrm{K})$ were determined by means of flame photometry (Lasany Model 1832, Lasany International, Haryana, India); phosphorus (P) with the molybdate/vanadate method (yellow method) by means of spectrophotometry (Multiskan GO, Thermo Fischer Scientific, Massachusetts, USA); nitrogen (N) with the Kjeldahl method (BUCHI, Digest Automat K-439 and Distillation Kjelflex K-360, Switzerland); and calcium (Ca), magnesium (Mg), copper (Cu) and zinc $(\mathrm{Zn})$ by means of an atomic absorption spectrophotometer (PG Instruments AA500FG, Leicestershire, UK), following the method of Chrysargyris et al. [37]. Plant mineral content was expressed in $\mathrm{g} \mathrm{kg}^{-1}$ and $\mathrm{mg} \mathrm{kg}^{-1}$ of dry weight for macronutrients and micronutrients, respectively.

\subsection{Hydrogen Peroxide, Lipid Peroxidation, Antioxidative Enzyme Activities and Proline Content}

Four replicates (each replicate was a pool of two plants) for each treatment were used for leaf damage index and antioxidant enzyme activity determinations. Lipid peroxidation and hydrogen peroxide $\left(\mathrm{H}_{2} \mathrm{O}_{2}\right)$ content were assessed according to the methods of Loreto and Velikova [38] and De Azecedo Neto et al. [39], respectively. The results were expressed as $\mu \mathrm{mol} \mathrm{H}_{2} \mathrm{O}_{2}$ per $\mathrm{g}$ of fresh weight, whereas lipid peroxidation was calculated as the malondialdeyde (MDA) content (nmol of MDA per $g$ of fresh weight).

The enzyme antioxidant activity of superoxide dismutase (SOD), catalase (CAT) peroxidase activity (POD) and ascorbate peroxidase (APX) was assayed as described previously by Chrysargyris et al. [40,41]. Results were expressed as enzyme units per mg of protein. The protein content was determined using bovine serum albumin (BSA) as a standard.

Proline was measured via the method using acid-ninhydrin and toluene at $520 \mathrm{~nm}$, as described by Khedr et al. [42]. The amount of proline was calculated using a standard curve of proline and results were expressed as $\mu \mathrm{g}$ proline per gram fresh weight. 


\subsection{Statistical Analysis}

Data were tested for normality before analysis and then subjected to one-way analysis of variance (ANOVA). Significant differences between mean values were determined using Tukey's HSD test. Statistical analyses were performed using the SPSS v. 22.0 program (IBM Corp., Armonk, NY, USA).

\section{Results}

The effects of salinity and high conductivity on geranium and verbena plant growth parameters are presented in Table 1. In geraniums, salinity resulted in decreased plant fresh biomass compared to the control treatment (reduced by $21.5 \%$ ), mainly due to the decreased plant height (reduced by $18.1 \%$ ), since the number of leaves remained unaffected. Moreover, the dry biomass of geranium plants was similar among the studied treatments. In the case of verbena, salinity decreased the plant biomass (both fresh and dry weight were reduced by $38.2 \%$ and $41.2 \%$, respectively), as well as the number of leaves (by $23.8 \%$ ) compared to the control treatment, whereas plant height was significantly increased compared to control and high-conductivity treatments (by $6.0 \%$ and $11.3 \%$, respectively). High-conductivity treatment had similar effects as the control for all the tested parameters.

Table 1. Influence of salinity $\left(75 \mathrm{mM} \mathrm{NaCl} ; 8.5 \mathrm{dS} \mathrm{m} \mathrm{m}^{-1}\right)$ and high conductivity $\left(8.5 \mathrm{dS} \mathrm{m} \mathrm{m}^{-1}\right)$ on plant height (cm), number of leaves, and fresh and dry weight biomass $(\mathrm{g})$ of geranium and verbena plants grown hydroponically in perlite substrate (mean $\pm \mathrm{SE}, \mathrm{n}=6$ ).

\begin{tabular}{|c|c|c|c|c|c|c|}
\hline & \multicolumn{3}{|c|}{ Geranium } & \multicolumn{3}{|c|}{ Verbena } \\
\hline & $\begin{array}{c}\text { Control } \\
\left(2.1 \mathrm{dS} \mathrm{m}^{-1}\right)\end{array}$ & $\begin{array}{c}\text { Salinity } \\
\text { (75 mM NaCl) } \\
\left(8.5 \mathrm{dS} \mathrm{m}^{-1}\right)\end{array}$ & $\begin{array}{l}\text { High } \\
\text { Conductivity } \\
\left(8.5 \mathrm{dS} \mathrm{m}^{-1}\right)\end{array}$ & $\begin{array}{c}\text { Control } \\
\left(2.1 \mathrm{dS} \mathrm{m}^{-1}\right)\end{array}$ & $\begin{array}{c}\text { Salinity } \\
\text { (75 mM NaCl) } \\
\left(8.5 \mathrm{dS} \mathrm{m}^{-1}\right)\end{array}$ & $\begin{array}{c}\text { High } \\
\text { Conductivity } \\
\left(8.5 \mathrm{dS} \mathrm{m}^{-1}\right)\end{array}$ \\
\hline Height $(\mathrm{cm})$ & $48.11 \pm 1.52 \mathrm{a}$ & $39.38 \pm 1.36 \mathrm{~b}$ & $48.10 \pm 3.56 \mathrm{a}$ & $16.41 \pm 0.18 b$ & $17.40 \pm 0.18 \mathrm{a}$ & $15.63 \pm 0.29 b$ \\
\hline Leaf No & $38.00 \pm 2.42 \mathrm{a}$ & $36.00 \pm 0.44 \mathrm{a}$ & $40.66 \pm 6.16 \mathrm{a}$ & $56.00 \pm 1.65 \mathrm{a}$ & $42.66 \pm 4.75 b$ & $65.50 \pm 0.22 \mathrm{a}$ \\
\hline $\begin{array}{l}\text { Biomass fresh } \\
\text { weight }(\mathrm{g})\end{array}$ & $62.02 \pm 2.47 \mathrm{a}$ & $48.70 \pm 3.37 b$ & $56.92 \pm 5.24 \mathrm{ab}$ & $4.63 \pm 0.33 a$ & $2.86 \pm 0.24 b$ & $5.14 \pm 0.29 \mathrm{a}$ \\
\hline $\begin{array}{c}\text { Biomass dry } \\
\text { weight }(g)\end{array}$ & $8.10 \pm 0.61 \mathrm{a}$ & $7.42 \pm 0.49 \mathrm{a}$ & $9.26 \pm 1.52 \mathrm{a}$ & $0.85 \pm 0.05 \mathrm{a}$ & $0.50 \pm 0.05 b$ & $0.94 \pm 0.08 \mathrm{a}$ \\
\hline
\end{tabular}

Means in the same row and the same species followed by the same Latin letter are not significantly different at $p<0.05$.

Salinity and high-conductivity treatments increased (by up to $831 \%$ and $320 \%$, respectively) stomatal resistance (highlighting the decreased stomatal conductance) but decreased leaf chlorophyll fluorescence (by $6.0 \%$ and $4.8 \%$, respectively) and the SPAD index (by $46.0 \%$ and $24.0 \%$, respectively) in geranium plants when compared to the control treatment (Table 2). Chlorophyll a, b and total chlorophyll content in geranium were not affected by either salinity or high conductivity. In the case of verbena, stomatal resistance increased in salinity and high-conductivity treatments by up to $356 \%$ and $229 \%$, respectively, compared to the control. Similarly to geranium plants, chlorophyll fluorescence and the SPAD index were reduced in both treatments; reductions of $6.2 \%$ and $7.4 \%$ were observed in chlorophyll fluorescence and reductions of $41.0 \%$ and $33.0 \%$ in SPAD index, for salinity and high-conductivity treatments, respectively. In common verbena, the content of chlorophyll a and, as a consequence, the content of total chlorophylls was negatively affected by salinity treatment in comparison to the high EC-treated plants (reductions of $41.7 \%$ and $37.0 \%$ for chlorophyll a and total chlorophylls content, respectively), but no significant differences were found in comparison to the control treatment. 
Table 2. Influence of salinity $\left(75 \mathrm{mM} \mathrm{NaCl} ; 8.5 \mathrm{dS} \mathrm{m}^{-1}\right)$ and high electrical conductivity $\left(8.5 \mathrm{dS} \mathrm{m} \mathrm{m}^{-1}\right)$ on leaf stomatal resistance $\left(\mathrm{cm} \mathrm{s}^{-1}\right)$, leaf fluorescence $(\mathrm{Fv} / \mathrm{Fm})$, SPAD index, chlorophyll (Chl a, Chl b, Total Chl) content (mg g ${ }^{-1}$ fresh weight-Fw) in geranium and verbena plants grown hydroponically in perlite substrate $(\operatorname{mean} \pm \mathrm{SE}, \mathrm{n}=6)$.

\begin{tabular}{|c|c|c|c|c|c|c|}
\hline & \multicolumn{3}{|c|}{ Geranium } & \multicolumn{3}{|c|}{ Verbena } \\
\hline & $\begin{array}{c}\text { Control } \\
\left(2.1 \mathrm{dS} \mathrm{m}^{-1}\right)\end{array}$ & $\begin{array}{c}\text { Salinity } \\
(75 \mathrm{mM} \mathrm{NaCl}) \\
\left(8.5 \mathrm{dS} \mathrm{m}^{-1}\right)\end{array}$ & $\begin{array}{c}\text { High } \\
\text { Conductivity } \\
\left(8.5 \mathrm{dS} \mathrm{m}^{-1}\right)\end{array}$ & $\begin{array}{c}\text { Control } \\
\left(2.1 \mathrm{dS} \mathrm{m}^{-1}\right)\end{array}$ & $\begin{array}{c}\text { Salinity } \\
\text { (75 mM NaCl) } \\
\left(8.5 \mathrm{dS} \mathrm{m}^{-1}\right)\end{array}$ & $\begin{array}{c}\text { High } \\
\text { Conductivity } \\
\left(8.5 \mathrm{dS} \mathrm{m}^{-1}\right)\end{array}$ \\
\hline $\begin{array}{l}\text { Stomatal resistance } \\
\left(\mathrm{cm} \mathrm{s}^{-1}\right)\end{array}$ & $1.16 \pm 0.36 c$ & $10.80 \pm 0.87 \mathrm{a}$ & $4.87 \pm 0.74 \mathrm{~b}$ & $2.61 \pm 0.31 c$ & $11.90 \pm 1.55 \mathrm{a}$ & $8.59 \pm 0.75 b$ \\
\hline $\begin{array}{l}\text { Chlorophyll } \\
\text { fluorescence } \\
\text { (Fv/Fm) }\end{array}$ & $0.83 \pm 0.00 \mathrm{a}$ & $0.78 \pm 0.01 b$ & $0.79 \pm 0.00 \mathrm{~b}$ & $0.81 \pm 0.01 \mathrm{a}$ & $0.76 \pm 0.00 \mathrm{~b}$ & $0.75 \pm 0.01 b$ \\
\hline SPAD & $110.80 \pm 1.72 \mathrm{a}$ & $59.86 \pm 3.84 \mathrm{c}$ & $84.20 \pm 8.17 b$ & $43.17 \pm 3.06 \mathrm{a}$ & $25.47 \pm 1.71 \mathrm{~b}$ & $28.92 \pm 2.62 b$ \\
\hline $\begin{array}{l}\text { Chlorophyll a (mg } \\
\left.\mathrm{g}^{-1} \mathrm{Fw}\right)\end{array}$ & $0.85 \pm 0.06 \mathrm{a}$ & $0.80 \pm 0.04 \mathrm{a}$ & $0.86 \pm 0.05 \mathrm{a}$ & $1.15 \pm 0.16 \mathrm{ab}$ & $0.84 \pm 0.12 \mathrm{~b}$ & $1.44 \pm 0.13 \mathrm{a}$ \\
\hline $\begin{array}{l}\text { Chlorophyll b (mg } \\
\left.\mathrm{g}^{-1} \mathrm{Fw}\right)\end{array}$ & $0.28 \pm 0.02 \mathrm{a}$ & $0.25 \pm 0.03 \mathrm{a}$ & $0.28 \pm 0.02 \mathrm{a}$ & $0.34 \pm 0.04 \mathrm{a}$ & $0.30 \pm 0.03 \mathrm{a}$ & $0.37 \pm 0.02 \mathrm{a}$ \\
\hline $\begin{array}{l}\text { Total Chlorophylls } \\
\quad\left(\mathrm{mg} \mathrm{g}^{-1} \mathrm{Fw}\right)\end{array}$ & $1.13 \pm 0.08 \mathrm{a}$ & $1.05 \pm 0.07 \mathrm{a}$ & $1.14 \pm 0.07 \mathrm{a}$ & $1.49 \pm 0.21 \mathrm{ab}$ & $1.14 \pm 0.11 b$ & $1.81 \pm 0.15 \mathrm{a}$ \\
\hline
\end{tabular}

Means in the same row and the same species followed by the same Latin letter are not significantly different at $p<0.05$.

The content of total phenols, total flavonoids and the antioxidant activity as assayed by FRAP and DPPH were significantly decreased compared to the control treatment only in the case of saline-treated geranium plants, whereas high conductivity did not affect any of the studied parameters (Figure 2A-D).
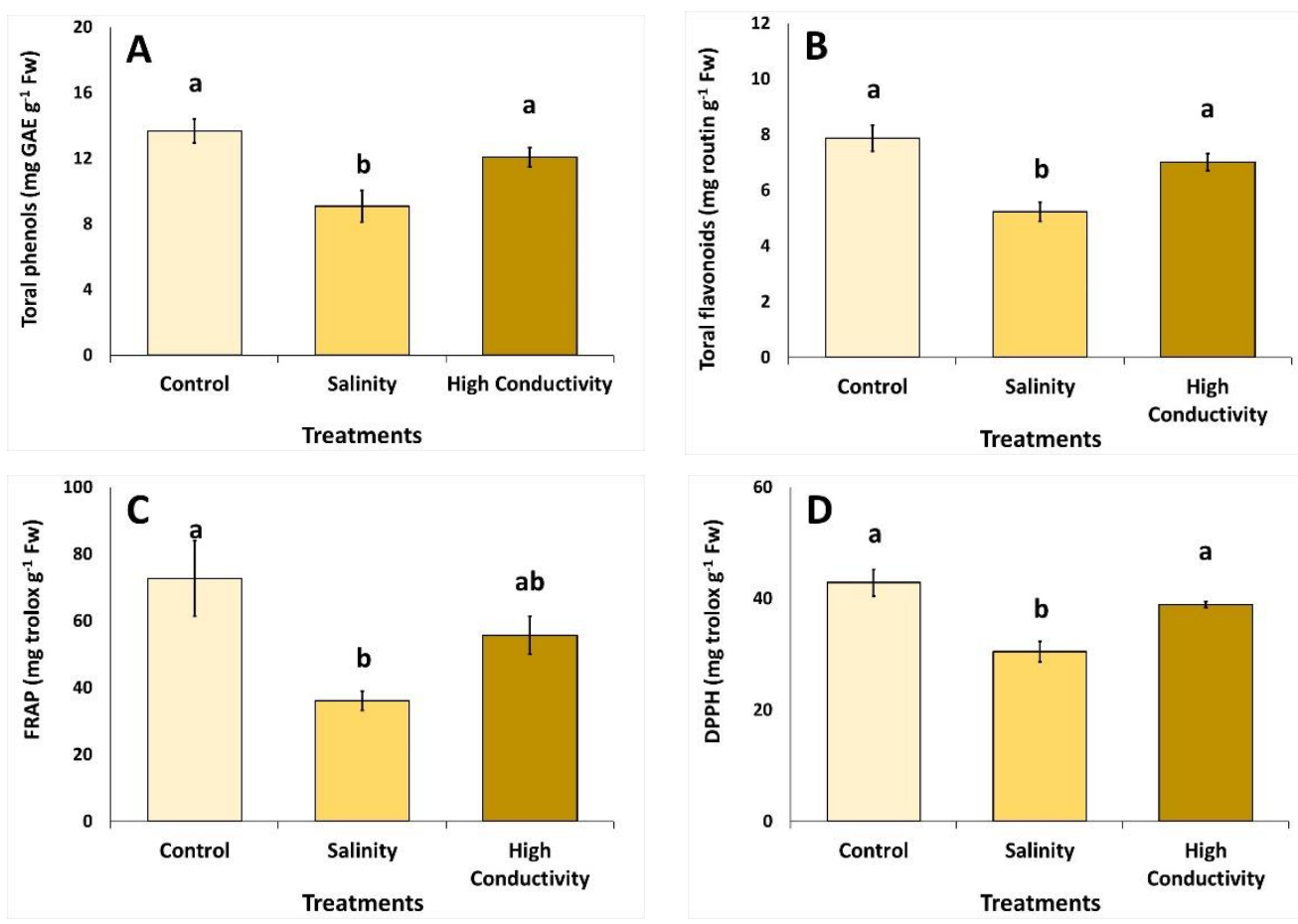

Figure 2. Influence of salinity $(75 \mathrm{mM} \mathrm{NaCl})$ and high electrical conductivity $\left(8.5 \mathrm{dS} \mathrm{m}^{-1}\right)$ on $(\mathrm{A})$ total phenols (mg GAE $\mathrm{g}^{-1}$ $\mathrm{fw}$ ), (B) total flavonoids ( $\mathrm{mg}$ routin $\mathrm{g}^{-1} \mathrm{fw}$ ) and antioxidant activity, assayed by (C) FRAP and (D) DPPH (mg trolox $\mathrm{g}^{-1}$ fw) methods, on geranium plants grown hydroponically in perlite substrate. Significant differences $(p<0.05)$ are indicated by different letters above each bar. Error bars show SE $(n=4)$.

On the other hand, in verbena plants, salinity decreased the content of total phenols (Figure 3A) but increased the content of total flavonoids and the antioxidant activity as assayed by DPPH compared to the control (Figure 3B,D). No significant differences were 
observed between the control and salinity treatments in the case of antioxidant activity determined by the FRAP assay. Similarly, high conductivity also decreased the total phenol content of verbena plants (Figure 3A); however, no significant differences between the control and the high-conductivity treatments were observed for total flavonoids and antioxidant activity (Figure 3B-D).
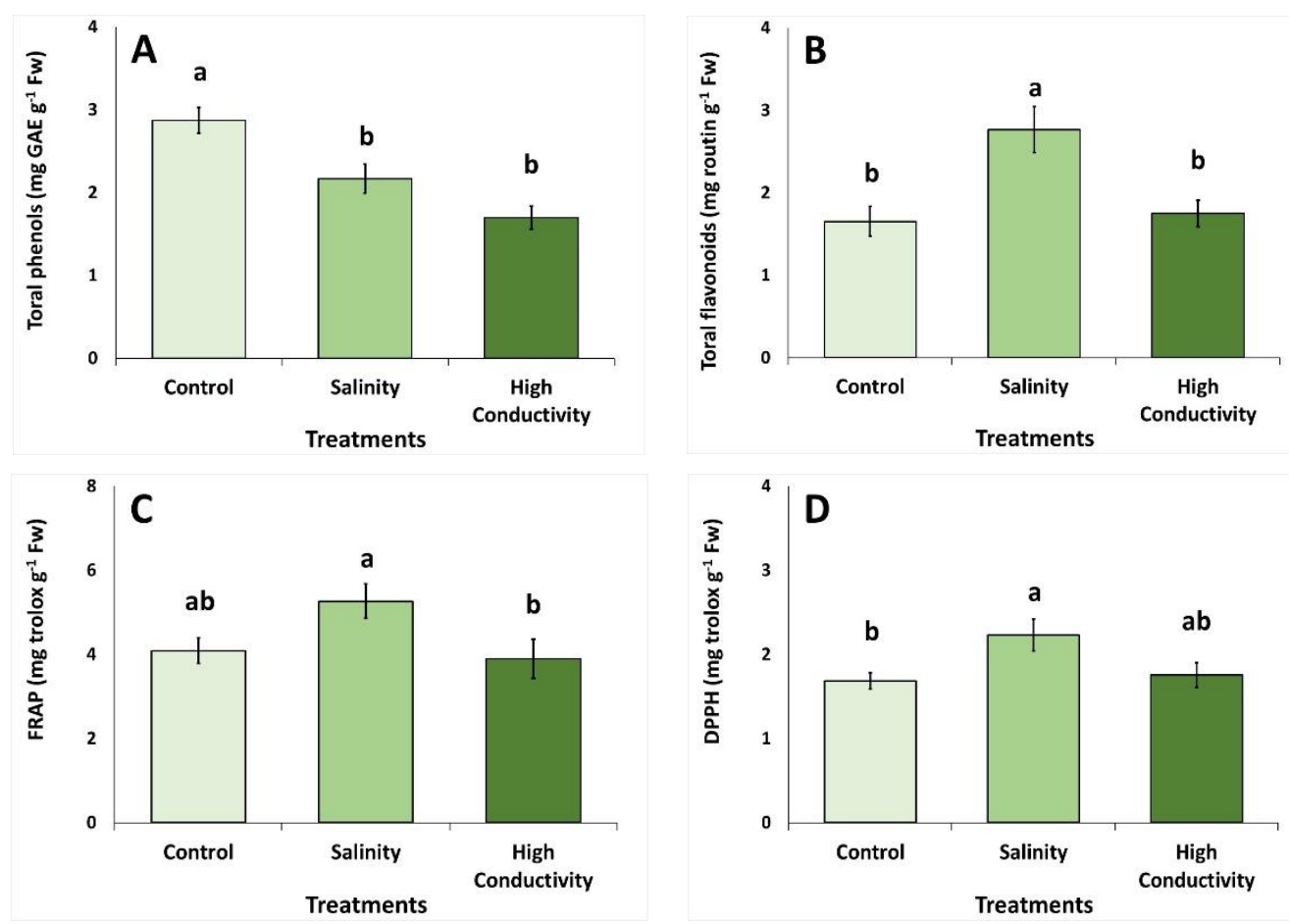

Figure 3. Influence of salinity $(75 \mathrm{mM} \mathrm{NaCl})$ and high electrical conductivity $\left(8.5 \mathrm{dS} \mathrm{m} \mathrm{m}^{-1}\right)$ on (A) total phenols (mg GAE $\left.\mathrm{g}^{-1} \mathrm{fw}\right),\left(\right.$ B) total flavonoids (mg routin $\mathrm{g}^{-1} \mathrm{fw}$ ), and antioxidant activity, assayed by (C) FRAP and (D) DPPH (mg trolox $\left.\mathrm{g}^{-1} \mathrm{fw}\right)$ methods, on verbena plants grown in perlite substrate. Significant differences $(p<0.05)$ are indicated by different letters above each bar. Error bars show SE $(n=4)$.

Regarding the nutrient content of geranium leaves, salinity decreased the N, K, P, and $\mathrm{Mg}$ content but increased $\mathrm{Na}$ and $\mathrm{Ca}$ content compared to the control treatment, whereas no differences were observed in the case of $\mathrm{Cu}$ and $\mathrm{Zn}$ content (Figure 4). In the case of high conductivity, $\mathrm{K}, \mathrm{P}, \mathrm{Ca}, \mathrm{Zn}$ and $\mathrm{Cu}$ levels were increased in comparison to the control treatment, whereas $\mathrm{N}$ and $\mathrm{Mg}$ remained unaffected.

In saline-treated verbena plants, salinity increased $\mathrm{K}, \mathrm{P}, \mathrm{Na}, \mathrm{Cu}$ and $\mathrm{Zn}$ content compared to the control treatment, whereas no differences were found in $\mathrm{N}$ and Ca levels (Figure 5). In the case of high conductivity, all nutrients increased when compared to the control treatment, except for $\mathrm{Na}$ and $\mathrm{Ca}$, for which no significant differences were observed.

The effects of salinity $(75 \mathrm{mM} \mathrm{NaCl})$ and high conductivity $\left(8.5 \mathrm{dS} \mathrm{m}^{-1}\right)$ on the leaf damage index, proline and antioxidant enzyme activities of geranium plants are presented in Figure 6. Saline-treated geranium revealed a reduced MDA content but increased antioxidant enzyme activity, as indicated by CAT, POD and APX content, as well as by the increased levels of proline (Figure $6 \mathrm{~A}, \mathrm{D}-\mathrm{G}$ ). In addition, the levels of $\mathrm{H}_{2} \mathrm{O}_{2}$ and SOD activity remained at similar levels to those in the control treatment (Figure 6B,C). Considering the effects of high conductivity, MDA content decreased but $\mathrm{H}_{2} \mathrm{O}_{2}, \mathrm{CAT}$, POD and APX increased in comparison to the control treatment. 

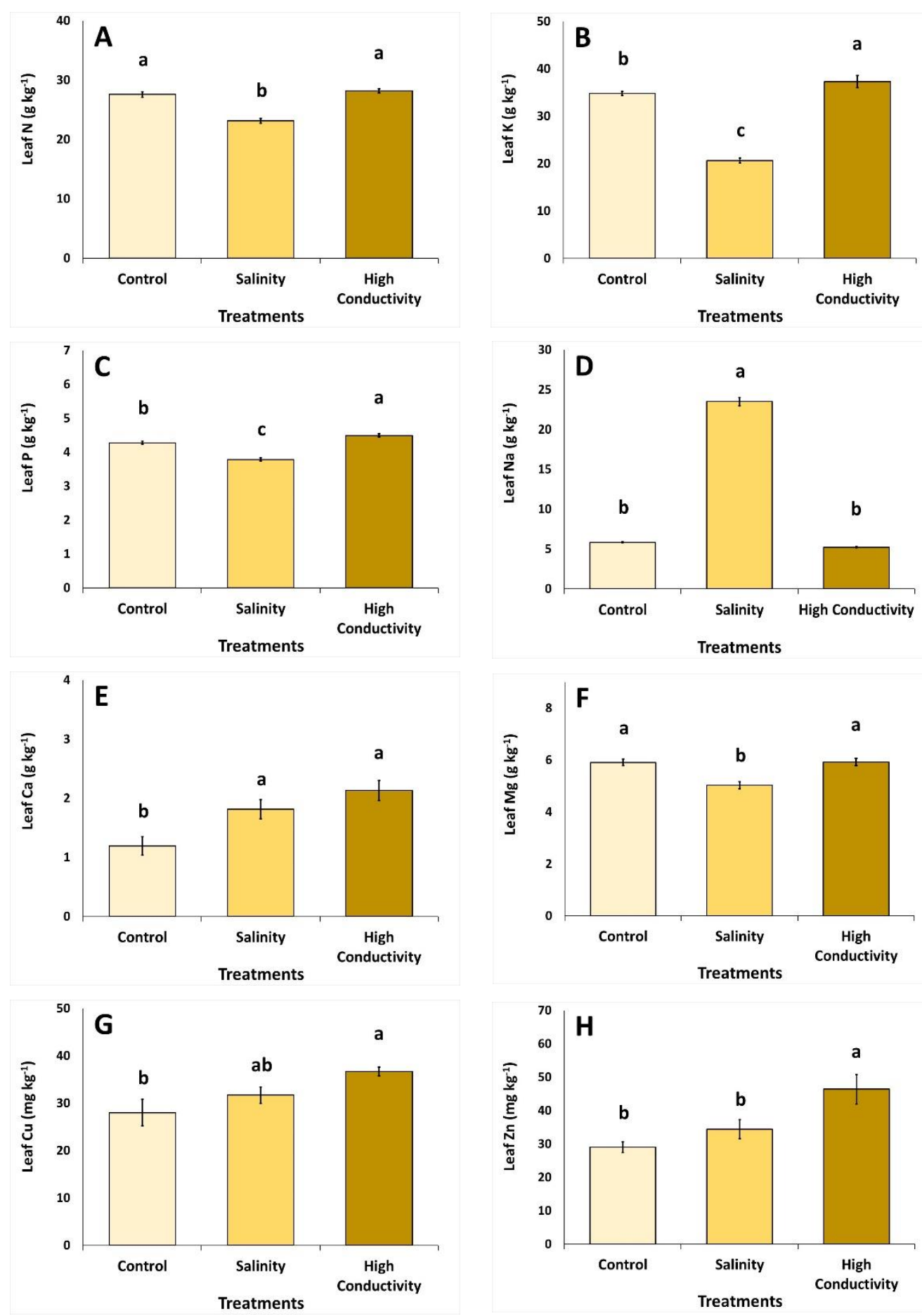

Figure 4. Influence of salinity $(75 \mathrm{mM} \mathrm{NaCl})$ and high conductivity $\left(8.5 \mathrm{dS} \mathrm{m}^{-1}\right)$ on the leaf content of macro- and micronutrients in geraniums grown hydroponically in perlite substrate. (A) nitrogen $-\mathrm{N},(\mathbf{B})$ potassium $-\mathrm{K},(\mathbf{C})$ phosphorus- $\mathrm{P}$, (D) sodium- Na, (E) calcium-Ca, (F) magnesium- Mg, (G) copper- $\mathrm{Cu}$ and $(\mathbf{H})$ zinc-Zn. Significant differences $(p<0.05)$ are indicated by different letters above each bar. Error bars show SE $(n=4)$. 

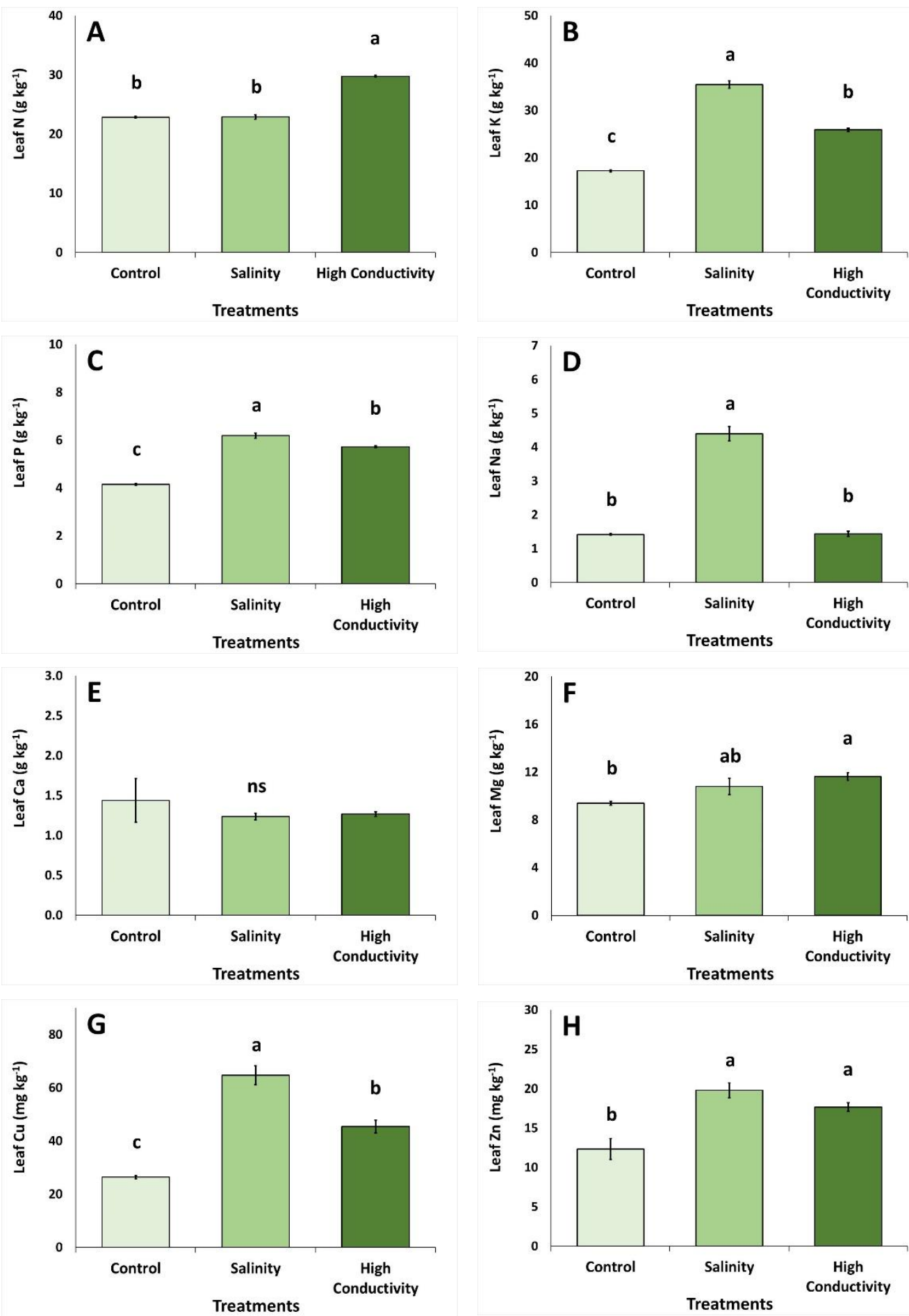

Figure 5. Influence of salinity $(75 \mathrm{mM} \mathrm{NaCl})$ and high conductivity $\left(8.5 \mathrm{dS} \mathrm{m}^{-1}\right)$ on the leaf content of macro- and micronutrients on verbena plants grown hydroponically in perlite substrate. (A) nitrogen-N, (B) potassium-K, (C) phosphorus-P, (D) sodium- $\mathrm{Na}$, (E) calcium- $-\mathrm{Ca},(\mathbf{F})$ magnesium $-\mathrm{Mg}$, (G) copper- $\mathrm{Cu}$ and $(\mathbf{H})$ zinc-Zn. Significant differences $(p<0.05)$ are indicated by different letters above each bar. Error bars show SE $(n=4)$. 

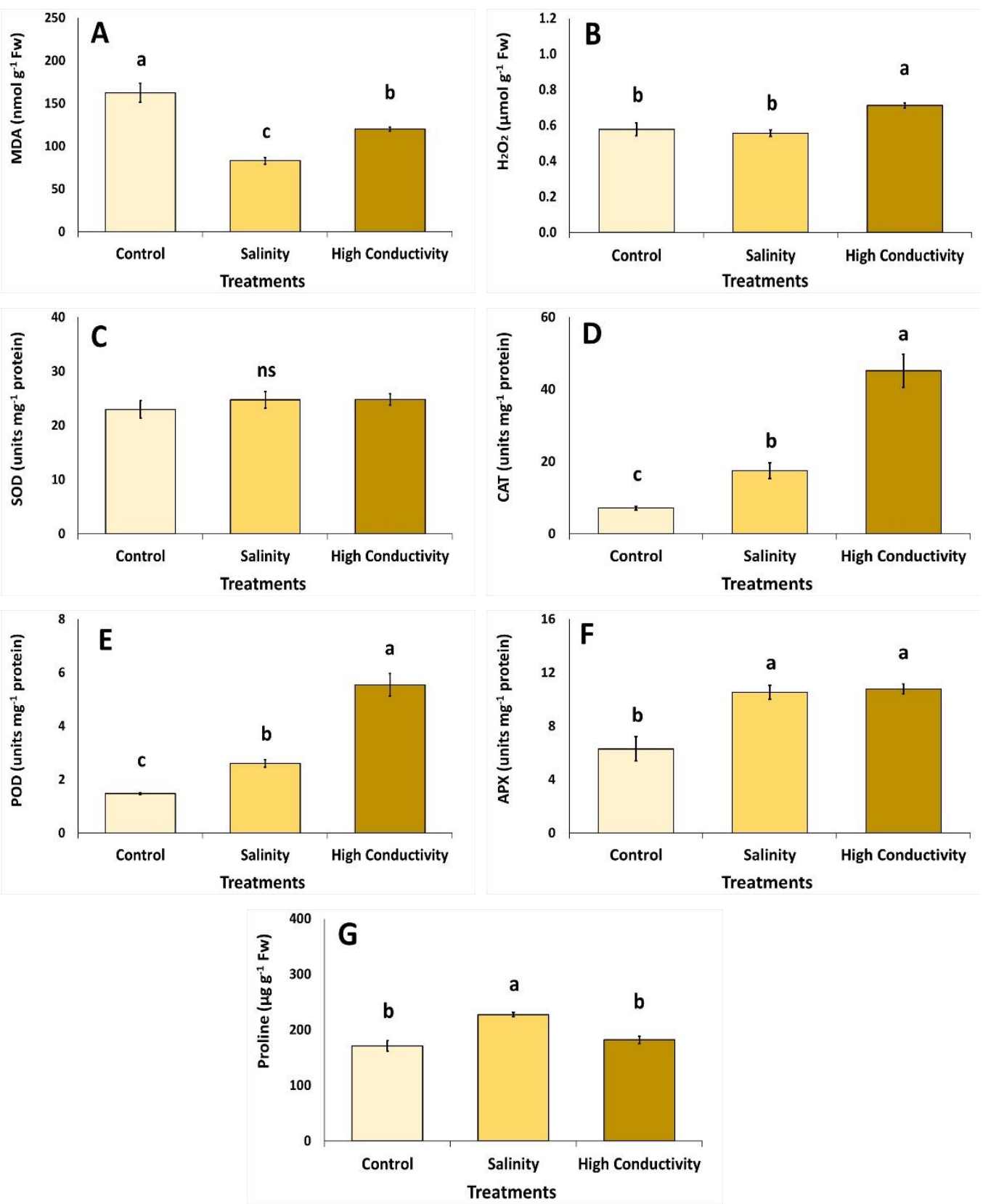

Figure 6. Influence of salinity $(75 \mathrm{mM} \mathrm{NaCl})$ and high conductivity $\left(8.5 \mathrm{dS} \mathrm{m}^{-1}\right)$ on the leaf damage index, proline and enzyme antioxidant activities on geranium grown in perlite. (A) lipid peroxidation-MDA, (B) hydrogen peroxide- $\mathrm{H}_{2} \mathrm{O}_{2}$, (C) superoxide dismutase-SOD, (D) catalase-CAT, (E) peroxidase activity-POD, (F) ascorbate peroxidase-APX and (G) proline. Significant differences $(p<0.05)$ are indicated by different letters. Error bars show SE $(n=4)$.

In verbena plants, salinity treatment increased MDA, SOD, POD, APX and proline contents but decreased the $\mathrm{H}_{2} \mathrm{O}_{2}$ concentration compared to the control treatment (Figure 7). Moreover, the level of CAT activity remained at similar levels in saline- and non-salinetreated verbena plants (Figure 7D). Regarding the effect of high conductivity, MDA and proline content increased but $\mathrm{H}_{2} \mathrm{O}_{2}$ and APX decreased in plants grown under highconductivity conditions when compared to the control treatment. 

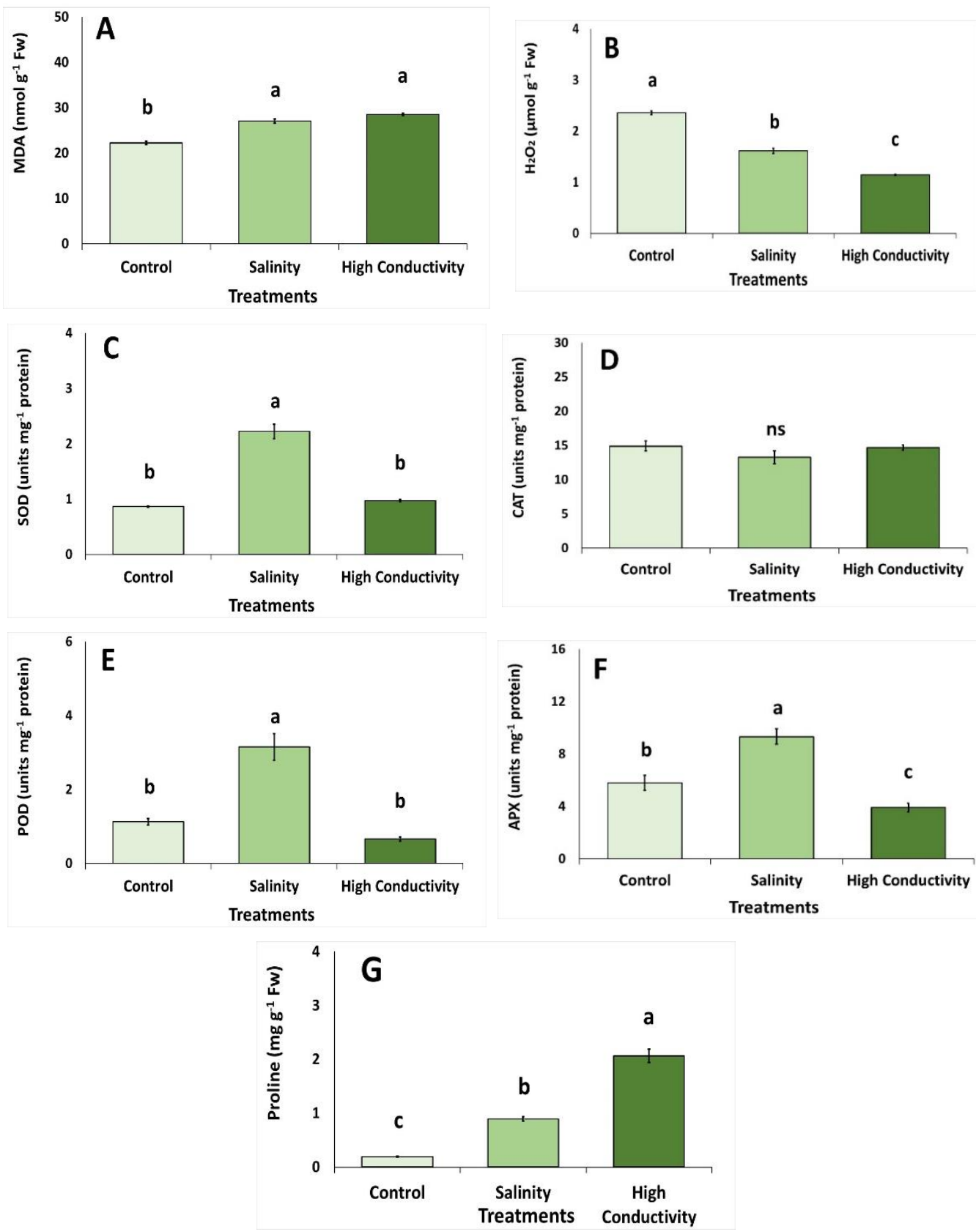

Figure 7. Influence of salinity $(75 \mathrm{mM} \mathrm{NaCl})$ and high conductivity $\left(8.5 \mathrm{dS} \mathrm{m}^{-1}\right)$ on the damage index, proline and enzyme antioxidant activities on verbena grown hydroponically in perlite substrate. (A) lipid peroxidation-MDA, (B) hydrogen peroxide $-\mathrm{H}_{2} \mathrm{O}_{2}$, (C) superoxide dismutase - SOD, (D) catalase-CAT, (E) peroxidase activity-POD, (F) ascorbate peroxidase-APX and $(\mathbf{G})$ proline. Significant differences $(p<0.05)$ are indicated by different letters. Error bars show SE $(\mathrm{n}=4)$.

\section{Discussion}

In hydroponic cultivation systems, an increased level of EC in the nutrient solution i.e., 3.0-4.0 dS m ${ }^{-1}$, is a well-known cultivation practice, usually implemented to maintain high quality standards in MAPs, such as in dittany [43] and basil [44], but also in fruity vegetables such as tomatoes, in which quality parameters indicated by the content of total soluble solids and the fruits' nutritional value were found to be increased [17]. However, the upper levels of EC in nutrient solutions have to be considered for each species, since excessive EC values may decrease the osmotic potential of the nutrient solution and consequently result in delays in water transport from roots to fruits, with negative effects on fruit expansion 
and yield [18]. EC is elevated either by increasing the total ion concentration of the nutrient solution or by adding sodium chloride $(\mathrm{NaCl})$. The former approach can be accomplished by adjusting the injector dilution rate of the stock solutions, but the latter is more widely known by commercial growers as being more cost-effective and easier to facilitate [45]. The elevated EC may have negative effects on yield but can also positively affect the quality of the fresh produce, thus compromising any yield losses through the production of products with a high added value $[17,45]$.

Romero-Aranda et al. [46] reported that high EC achieved by a high salt concentration in the nutrient solution decreased several physiological parameters in hydroponically grown tomatoes, including plants' photosynthetic rate, stomatal conductance and transpiration rate, which is consistent with the findings of the present study for the decreased stomatal conductance (indicated by the increased stomatal resistance values) in both geranium and verbena plants. In addition, the decrease in the net photosynthetic rate is in line with the decreased stomatal conductance, and this can be observed at EC values $\geq 4.0 \mathrm{dS} \mathrm{m}^{-1}$, where $\mathrm{Na}$ accumulation in plant tissues may occur [45]. Thus, plants respond to salinity by closing their stomata, which further decreases photosynthetic capacity and leaf transpiration [47]. Stomatal closure also reflects the difference in canopy foliage temperature, which was found to be increased in salt-stressed plants in comparison to control plants [48]. Similarly to our study, stomatal conductance was decreased in salttreated Ipomoea pes-caprae [49], spearmint [32] and Tagetes plants [50]. In our study, the EC in the nutrient solution was regulated at $8.5 \mathrm{dS} \mathrm{m}^{-1}$ in both salinity and high-conductivity treatments, and stronger negative impacts on plant physiology were found in saline-treated plants compared to the high EC-treated plants, with the former having approximately five times higher $\mathrm{Na}$ content in their leaves. In addition, decreased values of leaf fluorescence (Fv/Fm) and leaf greenness (SPAD index) have been reported in salt-treated Jatropha curcas [51]. The chlorophyll content in stressed plants is a key indicator for visually evaluating a plant's health and photosynthetic capacity [2]. However, chlorophyll levels vary depending on plant species, salt stress level and experimental conditions [2,52]. In the present study, SPAD index values indicated decreased chlorophyll concentrations in plants. However, as reviewed by Acosta-Motos et al. [14], salt-tolerant species show increased or unchanged chlorophyll contents under salinity conditions in comparison to salt-sensitive species, indicating that this parameter can be used as a biochemical marker for salt tolerance in plants. Similarly to the present findings, myrtle plants that were subjected to salinity, i.e., $4 \mathrm{dS} \mathrm{m}^{-1}$, for 15 days, had the same chlorophylls levels as the control treatment plants [53].

Total biomass decreased considerably (up to $21.5 \%$ and $38.2 \%$ ) in saline-treated geranium and verbena plants, respectively. Similarly, reports in the literature have suggested that in saline-treated chamomile, plant height and flower fresh and dry weight were also decreased [11]. Albornoz and Lieth [54] reported that the decreased lettuce yield when plants were exposed to high EC (i.e., 6 and $10 \mathrm{dS} \mathrm{m}^{-1}$ ) was related to decreased stomatal conductance and leaf area due to the formation of smaller leaves, since the number of leaves remained unaffected [7].

Abiotic stress may stimulate the biosynthesis of phenolic compounds, and salt-stressed plants may serve as potential sources of polyphenols [55]. The total phenol and antioxidant contents increased in high-EC-treated tomato plants, a finding that has been attributed to the plant response to the increased reactive oxygen species (ROS) associated with water stress [56]. However, other studies reported no differences in total phenols at moderate EC levels [57]. Moreover, an increase in the total phenol content was observed in sage (Salvia sclarea) plants only at low-moderate $(\leq 50 \mathrm{mM} \mathrm{NaCl})$ salinity levels, whereas it decreased in the case of more severe stress i.e., $75 \mathrm{mM} \mathrm{NaCl}$ [20]. This report is in accordance with the present findings, in which similar salinity levels were used, i.e., $75 \mathrm{mM} \mathrm{NaCl}$. In addition, Taarit et al. [20] reported that in saline conditions of $75 \mathrm{mM} \mathrm{NaCl}$, phenols were less effective in removing ROS because of the imbalance between ROS and antioxidant formation, resulting in the establishment of oxidative stress and/or the activation of 
complementary antioxidative mechanisms. In the present study, total flavonoids and DPPH antioxidant activity increased in saline-treated verbena plants, whereas in the case of geranium plants, total phenols, flavonoids and antioxidants decreased under saline conditions. This indicates the different responses of geranium and verbena plants to saline and high-EC conditions, as well as the presence of different antioxidant mechanisms, which induce the biosynthesis of different secondary metabolites (e.g., phenols and flavonoids). Therefore, in verbena plants, salinity and high EC conditions caused lipid peroxidation and accelerated plant stress, as indicated by the increased MDA and the activation of both non-enzymatic (flavonoids, DPPH and proline) and enzymatic (SOD, POD and APX) antioxidant mechanisms in response to the ROS challenge. In the case of geranium plants, the MDA levels in saline-treated plants decreased in comparison to the control treatment, indicating that oxidative stress probably took place at an earlier growth stage, as plants overreacted and employed both non-enzymatic (through decreasing the levels of phenols, flavonoids, FRAP and DPPH but increasing proline levels) and enzymatic (through increasing the levels of CAT, POD and APX) antioxidant mechanisms, against the oxidative stress (ROS) caused by saline conditions. Lipid peroxidation and the accumulation of MDA metabolites are indicative of oxidative damage to the cell membrane and the fact that these processes varied in salinity- and high EC-stressed geranium and verbena plants further highlights the different physiological responses and sensitivities of these plants to abiotic stress. Indeed, increased MDA was also found in salt-and alkali-stressed cotton plants, with stronger effects in the former [2]. Moreover, the activation of antioxidant defense enzymes (SOD, CAT, POD and APX) observed in the present study under salinity and high-EC conditions in nutrient solution has been well reported in previous studies $[32,50,58]$.

Proline is an amino acid that plays an important role in osmoregulation, redox buffering and energy transfer [59]. Plants that have been exposed to salt stress tend to accumulate proline as a first reaction to reduce their osmotic ability [60]. Proline and glycine betaine accumulate mainly in the cytoplasm and organelles accumulate in the vacuole to balance the osmotic pressure of ions, in response to high $\mathrm{Na}^{+}$and $\mathrm{Cl}^{-}$levels [13]. In our study, proline content increased in salt-stressed plants and in high-EC-treated verbena, indicating osmotic stress in both cases. Similarly to our study, the increase in the proline content under salinity stress has been well documented in cotton [2], pistachio [61], Ipomoea pes-caprae [49], Eugenia myrtifolia [62], spearmint [32] and Tagetes plants [50].

Regardless of the method used to regulate EC, water deficits (osmotic effects) may negatively affect crop performance when EC values are high [17] due to the imbalance in the transfer of nutrients from the roots to the upper parts of the plant. However, high EC during the early plant growth stages is reported to have beneficial effects since it allows for the building of strong cell walls in plants [18]. Sodium accumulation was evident in salinetreated plants in our study, and several recent reports indicate increased $\mathrm{Na}^{+}$absorption in salinity and drought exposure $[49,63]$, since Na may have a direct or indirect positive effect on other compounds involved in the osmotic adjustment [63]. However, plants subjected to salinity may exhibit osmotic and specific-ion injuries as well as nutritional disorders as a result of the impact of salinity on nutrients' availability and the competition in nutrient uptake, transport and partitioning within the plant [16]. Salinity also decreases phosphate uptake in soils and decreases $\mathrm{K}^{+}, \mathrm{Ca}^{2+}$ and $\mathrm{Mg}^{2+}$ uptake, as indicated by the decreased $\mathrm{P}$, $\mathrm{K}$ and $\mathrm{Mg}$ contents found in geranium in the present study. Additionally, the $\mathrm{N}$ content decreased as the reduction of $\mathrm{NO}_{3}{ }^{-}$uptake might be explained by the interaction between $\mathrm{NO}_{3}{ }^{-}$and $\mathrm{Cl}^{-}$at the site of ion transport [18]. However, contrasting results were observed in verbena, with saline-treated plants revealing increased contents in their leaves of most of the nutrients, thus highlighting the different responses of plant species to salinity and/or the differences in mineral requirements in both species. The relation of salinity and high EC with micronutrients is complex and salinity may increase, decrease or have no effect on micronutrient accumulation in plant tissues, depending on salinity levels, nutrient composition and growth conditions [18]. It has been reported that salinity increased $\mathrm{Zn}, \mathrm{Fe}$ and $\mathrm{Cu}$ levels [16], which is consistent with the current findings for verbena plants under 
salinity and for geranium and verbena plants under high-EC levels. On the other hand, $\mathrm{K}$ content decreased in geranium plants due to the increased salinity levels. However, opposite results were found in the case of verbena, where $\mathrm{K}$ content increased under saline conditions, indicating that $\mathrm{K}^{+}$may be preferably acquired and transported against a strong $\mathrm{Na}^{+}$concentration gradient [16].

\section{Conclusions}

These results indicate that high EC in the nutrient solution-obtained through increased levels of $\mathrm{NaCl}$ or through an increased concentration of minerals-may affect plant physiology and the accumulation of secondary metabolites, while at the same time activating several antioxidant mechanisms in response to the challenge of ROS formation and altering the accumulation of nutrients. Due to the increased antioxidant capacity and mineral accumulation observed under saline conditions in verbena compared to geranium plants, it is evident that verbena plants can more efficiently tolerate the studied salinity levels compared to geranium plants. Despite having the same EC levels, the ionic stress caused by high mineral concentrations in the nutrient solution is milder than the relevant osmotic stress caused by NaCl-induced salinity. Therefore, the regulation of EC levels in the nutrient solution by increasing the concentration of nutrients showed promising results, since it did not severely affect the crop performance of geranium and verbena plants. In conclusion, these results highlight the potential of using irrigation water of low quality in the cultivation of ornamental plants, with practical applications in landscaping in arid and semiarid regions. However, more studies with varied species are needed to identify tolerant species that are suitable for this practice, as well as to define the EC levels that cause less severe effects on crop performance.

Author Contributions: Conceptualization, A.C., S.A.P. and N.T.; methodology, A.C. and N.T.; software, A.C.; validation, A.C., S.A.P., D.P. and N.T.; formal analysis, A.C.; investigation, A.C.; resources, N.T.; data curation, A.C. and S.A.P.; writing-original draft preparation, A.C. and N.T.; writingreview and editing, A.C., S.A.P., D.P. and N.T.; visualization, A.C. and D.P.; supervision, N.T.; project administration, A.C. and N.T.; funding acquisition, N.T. All authors have read and agreed to the published version of the manuscript.

Funding: This research received no external funding.

Conflicts of Interest: The authors declare no conflict of interest.

\section{References}

1. Niu, G.; Rodriguez, D.S. Relative salt tolerance of five herbaceous perennials. HortScience 2006, 41, 1493-1497. [CrossRef]

2. Guo, H.; Hu, Z.; Zhang, H.; Min, W.; Hou, Z. Comparative Effects of Salt and Alkali Stress on Antioxidant System in Cotton (Gossypium Hirsutum L.) Leaves. Open Chem. 2019, 17, 1352-1360. [CrossRef]

3. Tzortzakis, N.G. Influence of $\mathrm{NaCl}$ and calcium nitrate on lettuce and endive growth using nutrient film technique. Int. J. Veg. Sci. 2009, 15, 44-56. [CrossRef]

4. Koubouris, G.C.; Tzortzakis, N.; Kourgialas, N.N.; Darioti, M.; Metzidakis, I. Growth, photosynthesis and pollen performance in saline water treated olive plants under high temperature. Int. J. Plant Biol. 2015, 6, 6. [CrossRef]

5. Chrysargyris, A.; Solomou, M.; Petropoulos, S.A.; Tzortzakis, N. Physiological and biochemical attributes of Mentha spicata when subjected to saline conditions and cation foliar application. J. Plant Physiol. 2019, 232, 27-38. [CrossRef] [PubMed]

6. Zhao, G.Q.; Ma, B.L.; Ren, C.Z. Growth, gas exchange, chlorophyll fluorescence, and ion content of naked oat in response to salinity. Crop. Sci. 2007, 47, 123-131. [CrossRef]

7. Giordano, M.; Petropoulos, S.A.; Cirillo, C.; Rouphael, Y. Biochemical, Physiological, and Molecular Aspects of Ornamental Plants Adaptation to Deficit Irrigation. Horticulturae 2021, 7, 107. [CrossRef]

8. Giordano, M.; Petropoulos, S.A.; Rouphael, Y. Response and Defence Mechanisms of Vegetable Crops against Drought, Heat and Salinity Stress. Agriculture 2021, 11, 463. [CrossRef]

9. Kalantari, E.; Hassanli, A.; Ghanbarian, G.A.; Ghaemi, A.A.; Mousavi, S.R. Local desalination treatment plant wastewater reuse and evaluation potential absorption of salts by the halophyte plants. Eurasian J. Soil Sci. 2018, 7, 43-50. [CrossRef]

10. Kelepesi, S.; Tzortzakis, N.G. Olive mill wastes: A growing medium component for seedling and crop production of lettuce and chicory. Int. J. Veg. Sci. 2009, 15, 325-339. [CrossRef]

11. Razmjoo, K.; Heydarizadeh, P.; Sabzalian, M.R. Effect of salinity and drought stresses on growth parameters and essential oil content of Matricaria chamomila. Int. J. Agric. Biol. 2008, 10, 451-454. 
12. Rozema, J. Growth, water and ion relationships of halophytic monocotyledonae and dicotyledonae; a unified concept. Aquat. Bot. 1991, 39, 17-33. [CrossRef]

13. Munns, R. Comparative physiology of salt and water stress. Plant Cell Environ. 2002, 25, 239-250. [CrossRef] [PubMed]

14. Acosta-Motos, J.R.; Ortuño, M.F.; Bernal-Vicente, A.; Diaz-Vivancos, P.; Sanchez-Blanco, M.J.; Hernandez, J.A. Plant responses to salt stress: Adaptive mechanisms. Agronomy 2017, 7, 18. [CrossRef]

15. Tzortzakis, N.; Nicola, S.; Savvas, D.; Voogt, W. Editorial: Soilless Cultivation Through an Intensive Crop Production Scheme. Management Strategies, Challenges and Future Directions. Front. Plant Sci. 2020, 11, 10-12. [CrossRef]

16. Grattan, S.; Grieve, C.M. Salinity-mineral nutrient relations in horticultural crops. Sci. Hortic. 1999, 78, 127-157. [CrossRef]

17. Moya, C.; Oyanedel, E.; Verdugo, G.; Flores, M.F.; Urrestarazu, M.; Álvaro, J.E. Increased electrical conductivity in nutrient solution management enhances dietary and organoleptic qualities in soilless culture tomato. HortScience 2017, 52, 868-872. [CrossRef]

18. Dorais, M.; Papadopoulos, A.P.; Gosselin, A. Influence of electric conductivity management on greenhouse tomato yield and fruit quality. Agronomie 2001, 21,367-383. [CrossRef]

19. Chrysargyris, A.; Loupasaki, S.; Petropoulos, S.A.; Tzortzakis, N. Salinity and cation foliar application: Implications on essential oil yield and composition of hydroponically grown spearmint plants. Sci. Hortic. 2019, 256, 108581. [CrossRef]

20. Taârit, M.B.; Msaada, K.; Hosni, K.; Marzouk, B. Fatty acids, phenolic changes and antioxidant activity of clary sage (Salvia sclarea L.) rosette leaves grown under saline conditions. Ind. Crops Prod. 2012, 38, 58-63. [CrossRef]

21. Parejo, I.; Viladomat, F.; Bastida, J.; Rosas-Romero, A.; Flerlage, N.; Burillo, J.; Codina, C. Comparison between the radical scavenging activity and antioxidant activity of six distilled and nondistilled mediterranean herbs and aromatic plants. J. Agric. Food Chem. 2002, 50, 6882-6890. [CrossRef]

22. Xylia, P.; Clark, A.; Chrysargyris, A.; Romanazzi, G.; Tzortzakis, N. Quality and safety attributes on shredded carrots by using Origanum majorana and ascorbic acid. Postharvest Biol. Technol. 2019, 155, 120-129. [CrossRef]

23. Hendawy, S.F.; Khalid, K.A. Response of Sage (Salvia officinalis L.) Plants to Zinc Application Under Different Salinity Levels. J. Appl. Sci. Res. 2014, 1, 147-155.

24. Salachna, P.; Piechocki, R. Effects of sodium chloride on growth and mineral nutrition of Purpletop vervain. J. Ecol. Eng. 2016, 17, 148-152. [CrossRef]

25. Fiz, O.; Vargas, P.; Alarcón, M.; Aedo, C.; García, J.L.; Aldasoro, J.J. Phylogeny and historical biogeography of Geraniaceae in relation to climate changes and pollination ecology. Syst. Bot. 2008, 33, 326-342. [CrossRef]

26. Colling, J.; Groenewald, J.H.; Makunga, N.P. Genetic alterations for increased coumarin production lead to metabolic changes in the medicinally important Pelargonium sidoides DC (Geraniaceae). Metab. Eng. 2010, 12, 561-572. [CrossRef]

27. Pandey, J.; Chand, S.; Chaurasiya, S.; Kumari, R.; Patra, D.D.; Verma, R.K.; Singh, S. Effect of tannery sludge amendments on the activity of soil enzymes and phytoremediation potential of two economically important cultivars of geranium (Pelargonium graveolens). Soil Sediment Contam. 2019, 28, 395-410. [CrossRef]

28. Khan, A.W.; Khan, A.U.; Ahmed, T. Anticonvulsant, anxiolytic, and sedative activities of Verbena officinalis. Front. Pharmacol. 2016, 7, 499. [CrossRef]

29. Batista, M.C.; Nascimento, R.; Júnior, S.D.O.M. Physiology and production of cherry tomato cultivars in a hydroponic system using brackish water. Braz. J. Agric. Environ. Eng. 2021, 25, 219-227.

30. Irakoze, W.; Prodjinoto, H.; Nijimbere, S.; Bizimana, J.B.; Bigirimana, J.; Rufyikiri, G.; Lutts, S. NaCl- and $\mathrm{Na}_{2} \mathrm{SO}_{4}$-Induced Salinity Differentially Affect Clay Soil Chemical Properties and Yield Components of Two Rice Cultivars (Oryza sativa L.) in Burundi. Agronomy 2021, 11, 571. [CrossRef]

31. Tzortzakis, N.G.; Economakis, C.D. Shredded maize stems as an alternative substrate medium: Effect on growth, flowering and yield of tomato in soilless culture. J. Veg. Sci. 2005, 11, 57-70. [CrossRef]

32. Chrysargyris, A.; Papakyriakou, E.; Petropoulos, S.A.; Tzortzakis, N. The combined and single effect of salinity and copper stress on growth and quality of Mentha spicata plants. J. Hazard. Mater. 2019, 368, 584-593. [CrossRef] [PubMed]

33. Chrysargyris, A.; Nikou, A.; Tzortzakis, N. Effectiveness of Aloe vera gel coating for maintaining tomato fruit quality. N. Zeal. J. Crop. Hortic. Sci. 2016, 44, 203-217. [CrossRef]

34. Wojdyło, A.; Oszmiański, J.; Czemerys, R. Antioxidant activity and phenolic compounds in 32 selected herbs. Food Chem. 2007, 105, 940-949. [CrossRef]

35. Tzortzakis, N.G.; Tzanakaki, K.; Economakis, C.D. Effect of origanum oil and vinegar on the maintenance of postharvest quality of tomato. Food Nutr. Sci. 2011, 02, 974-982. [CrossRef]

36. Meyers, K.J.; Watkins, C.B.; Pritts, M.P.; Liu, R.H. Antioxidant and Antiproliferative Activities of Strawberries. J. Agric. Food Chem. 2003, 51, 6887-6892. [CrossRef]

37. Chrysargyris, A.; Prasad, M.; Kavanagh, A.; Tzortzakis, N. Biochar type, ratio, and nutrient levels in growing media affects seedling production and plant performance. Agronomy 2020, 10, 1421. [CrossRef]

38. Loreto, F.; Velikova, V. Isoprene produced by leaves protects the photosynthetic apparatus against ozone damage, quenches ozone products, and reduces lipid peroxidation of cellular membranes. Plant Physiol. 2001, 127, 1781-1787. [CrossRef]

39. de Azevedo Neto, A.D.; Prisco, J.T.; Enéas-Filho, J.; de Abreu, C.E.B.; Gomes-Filho, E. Effect of salt stress on antioxidative enzymes and lipid peroxidation in leaves and roots of salt-tolerant and salt-sensitive maize genotypes. Environ. Exp. Bot. 2006, 56, 87-94. [CrossRef] 
40. Chrysargyris, A.; Xylia, P.; Botsaris, G.; Tzortzakis, N. Antioxidant and antibacterial activities, mineral and essential oil composition of spearmint (Mentha spicata L.) affected by the potassium levels. Ind. Crops Prod. 2017, 103, 202-212. [CrossRef]

41. Chrysargyris, A.; Charalambous, S.; Xylia, P.; Litskas, V.; Stavrinides, M.; Tzortzakis, N. Assessing the biostimulant effects of a novel plant-based formulation on tomato crop. Sustainability 2020, 12, 8432. [CrossRef]

42. Khedr, A.H.A.; Abbas, M.A.; Abdel Wahid, A.A.; Quick, W.P.; Abogadallah, G.M. Proline induces the expression of salt-stressresponsive proteins and may improve the adaptation of Pancratium maritimum L. to salt-stress. J. Exp. Bot. 2003, 54, $2553-2562$. [CrossRef]

43. Economakis, C. Effect of solution conductivity of growth and yield of Origanum dictamnus L. in nutrient film culture. Acta Hortic. 1992, 306, 204-209. [CrossRef]

44. Ciriello, M.; Pannico, A.; El-Nakhel, C.; Formisano, L.; Cristofano, F.; Duri, L.G.; Pizzolongo, F.; Romano, R.; De Pascale, S.; Colla, G.; et al. Sweet basil functional quality as shaped by genotype and macronutrient concentration reciprocal action. Plants 2020, 9, 1786. [CrossRef]

45. Wu, M.; Kubota, C. Effects of electrical conductivity of hydroponic nutrient solution on leaf gas exchange of five greenhouse tomato cultivars. Horttechnology 2008, 18, 271-277. [CrossRef]

46. Romero-Aranda, R.; Soria, T.; Cuartero, J. Tomato plant-water uptake and plant-water relationships under saline growth conditions. Plant Sci. 2001, 160, 265-272. [CrossRef]

47. Mohammadkhani, N.; Heidari, R. Water stress induced stomatal closure in two maize cultivars. Res. J. Biol. Sci. 2008, 3, 750-754.

48. Sirault, X.R.R.; James, R.A.; Furbank, R.T. A new screening method for osmotic component of salinity tolerance in cereals using infrared thermography. Funct. Plant Biol. 2009, 36, 970-977. [CrossRef]

49. Sucre, B.; Suárez, N. Effect of salinity and PEG-induced water stress on water status, gas exchange, solute accumulation, and leaf growth in Ipomoea pes-caprae. Environ. Exp. Bot. 2011, 70, 192-203. [CrossRef]

50. Chrysargyris, A.; Tzionis, A.; Xylia, P.; Tzortzakis, N. Effects of salinity on tagetes growth, physiology, and shelf life of edible flowers stored in passive modified atmosphere packaging or treated with ethanol. Front. Plant Sci. 2018, 871, 1-13. [CrossRef]

51. Dorta-Santos, M.A.; Barriola, I.; Wassner, D.F.; Ploschuk, E.L. Photosynthesis, fluorescence and mesophyll conductance responses to increasing salinity levels in Jatropha curcas at early vegetative stages. J. Agron. Crop. Sci. 2020, 206, 52-63. [CrossRef]

52. Xie, Z.X.; Duan, L.S.; Li, Z.H.; Wang, X.D.; Liu, X. Dose-Dependent Effects of Coronatine on Cotton Seedling Growth Under Salt Stress. J. Plant Growth Regul. 2015, 34, 651-664. [CrossRef]

53. Acosta-Motos, J.R.; Diaz-Vivancos, P.; Álvarez, S.; Fernández-García, N.; Sánchez-Blanco, M.J.; Hernández, J.A. NaCl-induced physiological and biochemical adaptative mechanisms in the ornamental Myrtus communis L. plants. J. Plant Physiol. 2015, 183, 41-51. [CrossRef]

54. Albornoz, F.; Heinrich Lieth, J. Over fertilization limits lettuce productivity because of osmotic stress. Chil. J. Agric. Res. 2015, 75, 284-290. [CrossRef]

55. Naczk, M.; Shahidi, F. Extraction and analysis of phenolics in food. J. Chromatogr. A 2004, 1054, 95-111. [CrossRef]

56. Krauss, S.; Schnitzler, W.H.; Grassmann, J.; Woitke, M. The influence of different electrical conductivity values in a simplified recirculating soilless system on inner and outer fruit quality characteristics of tomato. J. Agric. Food Chem. 2006, 54, 441-448. [CrossRef]

57. Ali, H.M.Z.; Ismail, G.S.M.; Mohamed, H.E.; Ismail, G.S.M. Tomato fruit quality as influenced by salinity and nitric oxide. Turk. J. Bot. 2014, 38, 122-129. [CrossRef]

58. Dewir, Y.H.; Chakrabarty, D.; Ali, M.B.; Hahn, E.J.; Paek, K.Y. Effects of hydroponic solution EC, substrates, PPF and nutrient scheduling on growth and photosynthetic competence during acclimatization of micropropagated Spathiphyllum plantlets. Plant Growth Regul. 2005, 46, 241-251. [CrossRef]

59. Toderich, K.; Shuyskaya, E.; Rakhmankulova, Z.; Bukarev, R.; Khujanazarov, T.; Zhapaev, R.; Ismail, S.; Gupta, S.K.; Yamanaka, N.; Boboev, F. Threshold tolerance of new genotypes of Pennisetum glaucum (L.) R. Br. to salinity and drought. Agronomy 2018, 8, 230. [CrossRef]

60. Ashraf, M.; Foolad, M.R. Roles of glycine betaine and proline in improving plant abiotic stress resistance. Environ. Exp. Bot. 2007, 59, 206-216. [CrossRef]

61. Azarmi, F.; Mozafari, V.; Abbaszadeh Dahaji, P.; Hamidpour, M. Biochemical, physiological and antioxidant enzymatic activity responses of pistachio seedlings treated with plant growth promoting rhizobacteria and Zn to salinity stress. Acta Physiol. Plant 2016, 38, 1-16. [CrossRef]

62. Acosta-Motos, J.R.; Diaz-Vivancos, P.; Álvarez, S.; Fernández-García, N.; Sanchez-Blanco, M.J.; Hernández, J.A. Physiological and biochemical mechanisms of the ornamental Eugenia myrtifolia L. plants for coping with $\mathrm{NaCl}$ stress and recovery. Planta 2015, 242, 829-846. [CrossRef]

63. Martínez, J.P.; Kinet, J.M.; Bajji, M.; Lutts, S. NaCl alleviates polyethylene glycol-induced water stress in the halophyte species Atriplex halimus L. J. Exp. Bot. 2005, 56, 2421-2431. [CrossRef] 